\title{
Multidisciplinary Collaboration for Environmental Protection using Biosensors. Detection of Organophosphate Insecticides in Aqueous Medium
}

\author{
M. Badea, ${ }^{a}$ M. Romanca, ${ }^{a}$ C. Draghici, ${ }^{a}$ J.-L. Marty, ${ }^{b}$ C. V. V. C. O. Marques, ${ }^{c}$ D. R. Mendes, ${ }^{c}$ \\ O. P. Amarante Jr. ${ }^{c}$ and G. S. Nunes ${ }^{*, c}$ \\ ${ }^{a}$ Biochemistry Research Group, Faculty of Medicine, Transilvania University of Brasov, 56, \\ Nicolae Balcescu St., 2200, Brasov, Romania \\ ${ }^{b}$ Lab. BIOMEM, University of Perpignan, 52, Av. Paul Alduy, 66860, Perpignan, France \\ ${ }^{c}$ Núcleo de Análise de Resíduos de Pesticidas (NARP), CCET, Universidade Federal do Maranhão,
} Av. Portugueses, s/n, Bacanga, 65080-040 São Luís-MA, Brazil

\begin{abstract}
Biossensores são um dos mais recentes campos da ciência, com ampla aplicação em biomonitoramento ambiental, medicina e análise de alimentos. Os biossensores eletroquímicos são sistemas de medida baseados na combinação de elementos bioquímicos e eletrônicos, incorporados em uma unidade. Este breve relatório apresenta algumas contribuições para resolver um tema muito importante na Romênia, na Europa e na América do Sul: detectar pesticidas organofosforados (OP's) em água, empregando sensores enzimáticos sensíveis e seletivos, baseados em enzimas acetilcolinesterases mutantes. Os estudos foram desenvolvidos através da colaboração entre três universidades (Universidade Federal do Maranhão, Brazil, Transilvania University of Brasov, Romania, and University of Perpignan, France), envolvendo pesquisadores e estudantes de diferentes campos: química analítica, bioquímica, microbiologia e eletrônica. O objetivo do estudo foi desenvolver e caracterizar biossensores altamente sensíveis para detecção de OP's em meio aquoso.
\end{abstract}

Biosensors are one of the recent scientific domains with large applicability in environmental biomonitoring, medicine, and food analysis. Electrochemical biosensors are measuring systems based on the combination of both biochemical and electronic elements in one unit. This short report presents contributions from Romania, Europe and South America to detect organophosphorus (OP) pesticides in water employing sensitive and specific enzymatic sensors based in mutant acetylcholinesterase enzymes. The studies were carried out by three universities (Universidade Federal do Maranhão, Brazil, Transilvania University of Brasov, Romania, and University of Perpignan, France), involving researchers and students with different backgrounds: analytical chemistry, biochemistry, microbiology, and electronics. The aim of the experimental study was to develop and to characterise highly sensitive enzymatic biosensors for OP detection in aqueous medium.

Keywords: AChE-biosensor, organophosphoorus pesticides, environmental protection

\section{Introduction}

Electronic sensors were developed in a period of time when automation and process control of analytical and clinical systems were introduced. Initially, macro-sensors using potentiometers, potentiostats, thermistors were developed as signal transducters. However they were difficult to obtain, had large mass and volume, used expensive materials, and required trained people to work

* e-mail: vandasn@terra.com.br with them. ${ }^{1,2}$ After 1950, the sensors, initially developed for industrial and medical applications, were used also in many different fields. ${ }^{3,4}$ Enzymology presents very important applications in medicine, the pharmaceutical, food and textile industries, contributing to inter-disciplinary fields developing: molecular biology, genetics engineering, microbiology, and biotechnology. Most of the developed analytical sensors are enzymatic biosensors. ${ }^{1,3}$

The use of pesticides in agriculture and in insect control has created a potential danger to both aquatic life and human health. Developed for pests, pesticides also represent a risk 
of toxicity for humans, some animals, birds as well as useful insects. ${ }^{5}$ Pesticides are highly toxic compounds and some of them (organophosphorus compounds, OP) are powerful inhibitors of enzymes involved in nerve functions (acetylcholinesterase, AChE).$^{6-8}$ For these reasons it is necessary to explain their action on living systems, and to monitor their presence in the environment. For instance, in the case of OP pesticides in water, the concern is that they can move through the soil into ground water and their polar metabolites may be transported to estuarine and coastal waters. Physicochemical characteristics such as salinity, turbidity and $\mathrm{pH}$, must be carefully considered when developing methods of analysis for traces of these organic compounds. ${ }^{9}$ In the case of biosensors, some of these parameters ( $\mathrm{pH}$, salinity) must be controlled, but generally there is minimal sample treatment, since biosensor operation is based on biological recognition. ${ }^{1,3}$

This report aims to describe a scientific collaboration research of students and researchers to determine organophosphorus pesticides in water using AChE-based biosensors as sensitive and specific enzymatic methods.

For this purpose, we organized a strong team including teachers with different backgrounds: analytical chemistry, biochemistry, microbiology, and electronics, making it possible to obtain reliable biosensors for organophosphorus pesticide detection. Our group was assisted by students; they have been trained to optimise a final configuration of an enzymatic biosensor for use in Romania and also in Brazil, having as a model the experiences already published. ${ }^{10-13}$

The first step in the study was the analysis of specialized literature information to identify the national and international level of scientific research in this field. ${ }^{14-17}$ We have chosen some organophosphorus pesticides as representative pollutants for analysis. ${ }^{7,8,14}$

\section{Experimental}

Using biosensors with immobilised electric eel (ee) acetylcholinesterase (Sigma, St. Louis, USA) and genetically modified acetylcholinesterase from Drosophila melanogaster (dros), obtained from Prof. Didier Fournier Group (Paul Sabatier University, Toulouse, France), amperometric determinations have allowed to study the enzymatic generated current intensity variation in the absence and in the presence of organophosphorus pesticide, by using a TCNQ-modified graphite electrode against $\mathrm{Ag} / \mathrm{AgCl}$ reference electrode. ${ }^{12,13,18}$

The three channel (reference, auxiliary and working electrodes) sensors were prepared on the PVC support by screen-printing technique with a DEK Model 248 printing machine (DEK Ltd, Weymouth, England). The following layers were successively printed: a silver conducting film; a carbon layer; a reference electrode, consisting of a $\mathrm{Ag} /$ $\mathrm{AgCl}$ paste printed over the carbon layer in one of the channels; the working electrode, containing the chemical mediator TCNQ mixed in graphite and HEC (in the other channel), and an insulating layer. This was prepared in order to leave uncovered only a $9 \mathrm{~mm}$ long portion of the silver track, necessary for the electrical contact. Detailed procedures for the preparation of TCNQ-modified screenprinted biosensors have been previously described. ${ }^{13,18}$

A 641 VA Methrohm detector imposing a constant potential of $100 \mathrm{mV}$ between the TCNQ-modified screenprinted working and reference $(\mathrm{Ag} / \mathrm{AgCl})$ electrodes was used. ${ }^{10,12,13,18}$ The current values were measured with a BD40 (Kipp \& Zonen, The Netherlands) recorder. Electrochemical measurements were performed by disposing the biosensor in a cell containing the acetylthiocoline (ATCh) substrate with constant magnetic stirring, and the electrical current was registered immediately after substrate addition, before and after enzyme incubation with the AChE-inhibitor. Relative inhibition (RI) was calculated by comparison of the current intensities registered before and after enzyme inhibition in presence of the pesticide. For a maximum precision, for each experimental condition we have selected the optimal measurement domain of the multimeter, in order to measure the currents generated in redox reaction from analyzed system.

A sol-gel method was tesed to immobilise the AChE enzyme, following the operational stability of the biosensors. Synthetic systems which contained known quantities of organophosphorus pesticides were studied. The precursors were used in the ratio TMOS (tetramethylorthosilicate): MTMOS (methyltrimethoxysilane): $\mathrm{H}_{2} \mathrm{O}: \mathrm{HCl}\left(1 \mathrm{mmol} \mathrm{L}^{-1}\right)$ : PEG600 (polyethylene glycol) equal to $10: 10: 44: 40: 4$ (v:v:v:v:v). TMOS, MTMOS and PEG600 were purchased from SigmaAldrich Co (Steinheim, Germany). The enzyme mixture was manually incorporated into the surface of the working electrode in order to have $1 \mathrm{mU}$ enzyme per electrode. Details of the enzyme immobilization procedure have been previously described. ${ }^{10}$

Analytical procedures and experimental results were evaluated. The calibration curves were useful for sensitive and specific organophosphorus pesticides analysis from water samples, identifying the eventual pollutant sources with this kind of compounds. Using the validated methods for organophosphorus pesticides detection from synthetic (reference solutions) and real water samples, the biosensor efficiency was also evaluated. 
Each experimental test was preceded by the enzymatic activity determination in order to obtain a constant activity in the analysed biosensor system, and also to study the stability of the enzymatic substrate (to observe its eventual degradation with the time. ${ }^{18}$

\section{Results and Discussions}

The enzymatic immobilisation on the working electrode using the sol-gel method involves the obtaining of a $\mathrm{SiO}_{2}$ network and the precursor polymerisation, resulting in a tetraedric network that includes the enzyme. This method involves two steps: precursor hydrolysis and the condensation in the presence of enzyme (Figure 1).

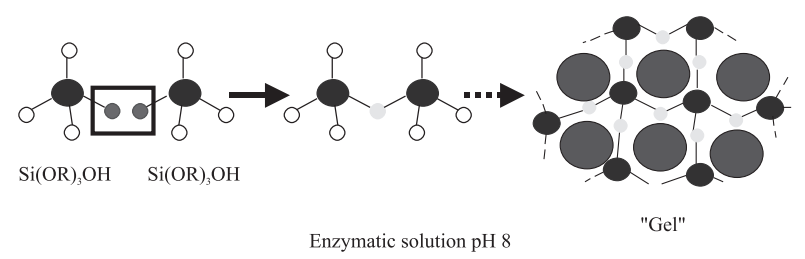

Figure 1. Scheme for the preparation of the sol-gel enzymatic paste.

The obtained sol-gel material gives important properties to the biosensor: rigidity, thermal and photochemical stability, functionality in water and organic environment. Thiocholine will be transformed into dithiocholine, in presence of redox mediator (TCNQ) liberating electrons (Figure 2).

The electrode calibration was carried out following the current intensity variations from analysis system. The current intensities resulted from successively injection, in the same quantity of buffer system, of known amounts of acetylthiocholine were plotted versus the final concentration of enzymatic substrate from reaction mixture.

For commercial (ee) acetylcholinesterase and for genetic mutant (dros) acetylcholinesterases B-003 and B079, electrical signal dependences on the substrate concentration are presented in Figure 3. Table 1 presents some regression parameters for optimization of [ATChCl], in order to select the substrate concentration range which provides adequate current values for future inhibition assays. A Michaelis-Menten allure can be seen, with a linear dependency for smaller substrate concentration, characterised by a correlation coefficient very close to unity for all cases. For higher substrate concentration, the dependence has a constant maximum value corresponding to the enzyme saturation with the substrate.

Also studied was the operational stability of the obtained biosensors when some controlled substrate

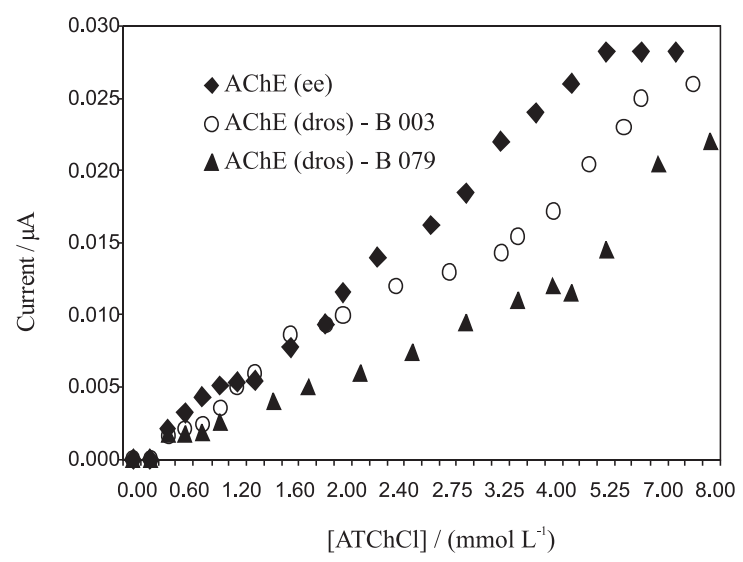

Figure 3. Dependence of electric signal on the acetylthiocholine concentration for the immobilized commercial and mutant acetylcholinesterases. Operational conditions: $1 \mathrm{mU}$ enzyme/electrode, working potential of 100 $\mathrm{mV}$ against $\mathrm{Ag} / \mathrm{AgCl}$ reference electrode, $\mathrm{pH} 7$.
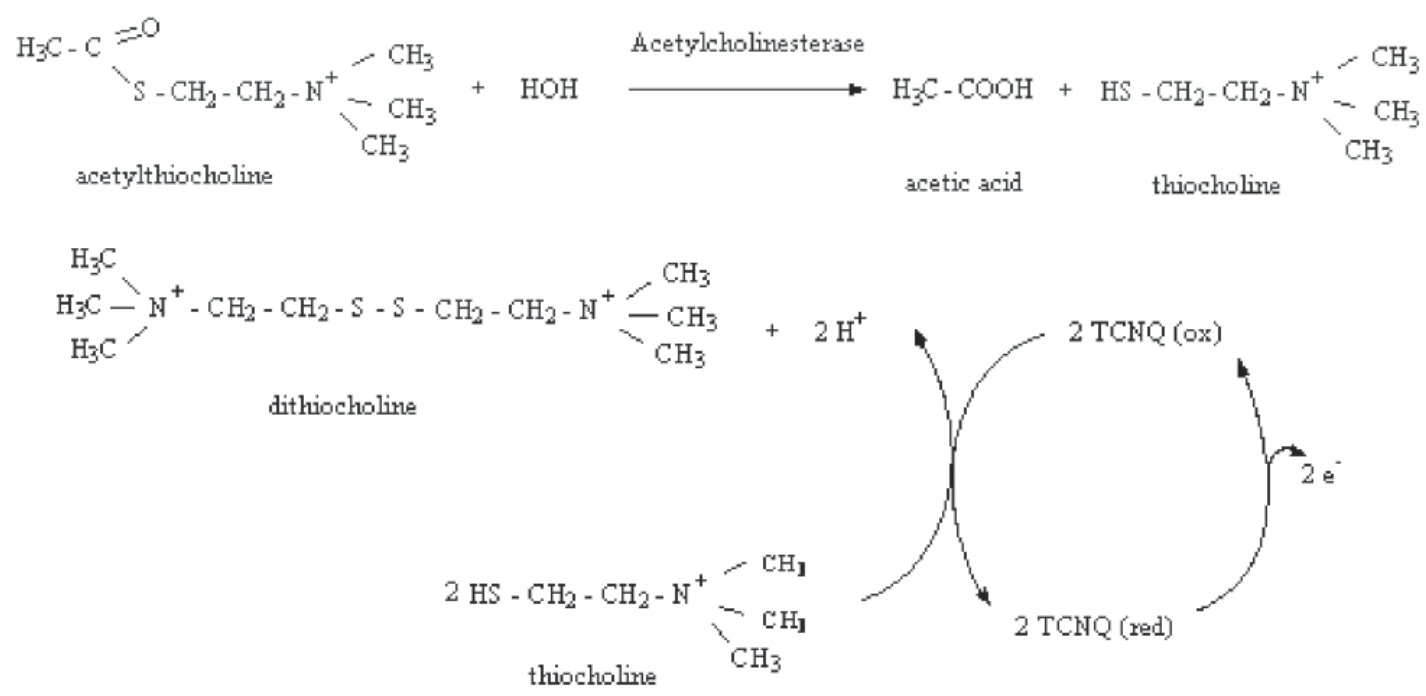

Figure 2. Hydrolysis of acetylthiocholine catalized by acetylcholinesterase enzyme and role of the TCNQ mediator at working electrode surface. 
Table 1. Regression parameters for the optimization of the substrate concentration using commercial and genetically modified enzymes

\begin{tabular}{lccc}
\hline Enzyme & $\mathrm{R}^{2}$ & $\begin{array}{c}\text { Linear Range } \\
\left(\mathrm{mmol} \mathrm{L}^{-1}\right)\end{array}$ & $\begin{array}{c}\text { Slope } \\
\left(\mathrm{mmol} \mathrm{L}^{-1}\right)\end{array}$ \\
\hline AChE (ee) & 0.997 & $0.3-5.2$ & 2.6 \\
AChE (dros) - B-003 & 0.992 & $0.2-2.8$ & 3.2 \\
AChE (dros) - B-079 & 0.995 & $0.15-5.0$ & 3.7 \\
\hline
\end{tabular}

concentrations were added to the systems. Relative standard deviation of the electrical current intensities obtained during enzymatic reaction were $1.1 \%-2.1 \%$ from the mean. These experimental results have demonstrated that the three obtaining enzyme sensors containing commercial and mutant acetylcholinesterases have shown good operational stability.

Studying the influence of azinphos methyl oxon over the biosensor response, some AChE (commercial and mutant)-based sensors were incubated with a $10^{-6} \mathrm{~mol} \mathrm{~L}^{-1}$ pesticide solution during $10 \mathrm{~min}$ at room temperature. The relative inhibitions, calculated according already described procedure, ${ }^{10,12,13,18}$ are presented in the Table 2 .

Table 2. Bimolecular inhibition rate constants and relative inhibition of commercial AChE (Sigma) and bio-engineered AChE (modified enzyme from Drosophila melanogaster) in presence of $10^{-6} \mathrm{~mol} \mathrm{~L}^{-1}$ azinphos methyl oxon solution

\begin{tabular}{lcc}
\hline Enzyme & $\begin{array}{c}\text { Inhibition constant } \\
\mathrm{K}_{\mathrm{i}}\left(\mu \mathrm{mol} \mathrm{L}^{-1}\right)^{\mathrm{a}}\end{array}$ & $\begin{array}{c}\text { Relative inhibition } \\
\mathrm{RI}(\%)^{\mathrm{b}}\end{array}$ \\
\hline AChE (ee) & 0.36 & 7.15 \\
AChE (dros) - B-003 & 600 & 23.71
\end{tabular}

${ }^{a} \mathrm{~K}_{\mathrm{i}}$ measured spectrophotometrically; ${ }^{18}{ }^{\mathrm{b}} \mathrm{RI}$ obtained through the AChEbiosensor. $^{13,18}$

A higher inhibition degree for genetically modified (dros) AChE in comparison with commercial (ee) AChE was observed, indicating that the enzyme engineering provided a higher sensitivity of the mutant enzyme to the azinphos methyl insecticide. This experimental conclusion may be explained by the higher inhibition constant for the B-003 enzyme in presence of azinphos methyl oxon, in comparison with the commercial enzyme. Further, others (dros) AChE were spectrophotometrically tested through inhibition with others organophosphorus pesticides: chlorpyrifos and chlorpyrifos oxon. Results presented in Table 3 have shown that for chlorpyriphos and chlorpyrifos oxon is better to use biosensors containing B-071 and B029 enzymes, respectively. This bio-engineered enzyme has presented a higher practical sensitivity to both inhibitors.

In order to monitor the one day-variation of acethylcholinesterase inhibition through incubation of the AChE-biosensor in aqueous medium, a variety of engineered (dros) AChE's can be successfully selected to prepare more sensitive biosensors. For instance, minimal concentrations of $1.3 \mu \mathrm{g} \mathrm{L}^{-1}$ and $6.4 \mu \mathrm{g} \mathrm{L}^{-1}$ for chlorpyrifos and chlorpyrifos oxon, respectively, caused a $10 \% \mathrm{RI}$ in B-029 AChE activity. These values were considered as the practical limits of detection for these compounds and the B-029 based biosensors can be considered useful for OP detection in water samples. A prior SPE extraction/ pre-concentration step should be employed in order to improve the biosensor sensitivity.

\section{Conclusions}

This work can contribute to the continuous improving activity of the researchers involved in this study, using their knowledge for student teaching in biochemistry, biotechnology and environmental protection fields, and also for their own multidisciplinary techniques (analytical chemistry, biochemistry, biophysics, statistics, electronics), stimulated by the work in this research team.

The students have used the obtained data for their own licence thesis and master, and also for scientific papers, after additional experiments in presence of OP pesticides from standard solutions and finally from real samples.

This fast analytical method may offer to different investigators an easy way to detect the presence of OP pesticides in different matrices, especially in water, being use like a sensitive screening method for environmental monitoring.

\section{Acknowledgments}

The authors would like thank Prof. Dr. Didier Fournier (Laboratoire de Synthèse et Physicochimie des Molecules

Table 3. Bimolecular inhibition rate constants and relative inhibition of bio-engineered B-71 and B-29 AChE (modified enzymes from Drosophila melanogaster) in presence of $1.710^{-6} \mathrm{~mol} \mathrm{~L}^{-1}$ chlorpyrifos and $2.510^{-9} \mathrm{~mol} \mathrm{~L}^{-1}$ chlorpyrifos oxon solutions

\begin{tabular}{|c|c|c|}
\hline Inhibitor & Inhibition constant $\left.\mathrm{K}_{\mathrm{i}}(\mu \mathrm{mol} \mathrm{L})^{-1}\right)^{\mathrm{a}}$ & Relative Inhibition RI $(\%)^{\mathrm{b}}$ \\
\hline \multirow[t]{2}{*}{ Chlorpyrifos } & AChE (dros) - B 071: 1.5 & AChE (dros) - B 071: 29.0 \\
\hline & AChE (dros) - B 029: 15.4 & AChE (dros) - B 029: 65.0 \\
\hline \multirow[t]{2}{*}{ Chlorpyrifos oxon } & AChE (dros) - B 071: 0.3 & AChE (dros) - B 071: 36.0 \\
\hline & AChE (dros) - B 029: 0.2 & AChE (dros) - B 029: 26.0 \\
\hline
\end{tabular}

${ }^{\mathrm{a}} \mathrm{K}_{\mathrm{i}}$ measured spectrophotometrically; ${ }^{18}{ }^{\mathrm{b}} \mathrm{RI}$ obtained through the AChE-biosensor. ${ }^{13,18}$ 
d'Intérêt Biologique UMR 5068, Université Paul Sabatier, Toulouse, France) for providing us the bio-engineered Drosophila melanogaster acetylcholinesterase enzymes used in this study. G. S. Nunes would like thank CNPq (Conselho Nacional de Desenvolvimento Científico e Tecnológico) for the fellowship and financial support.

\section{References}

1. Turner, A. P. F.; Karube, I.; Wilson, G. S.; Biosensors: Fundamentals and Applications, Oxford University Press: Oxford, 1987.

2. Eggins, B.; Biosensors: An Introduction, Wiley \& Teubner: London, 1996.

3. Cunninghan, A. J.; Introduction to Bioanalytical Sensors, John Wiley \& Sons: New York, 1998.

4. Girault, H. H.; Electrochimie Physique et Analytique, PPUR: Lausanne, 2001.

5. Hassal, K. A.; The Chemistry of Pesticides: Their Methabolism, Mode of Action and Uses in Crop Protection, MacMillan: New York, 1983.

6. Nunes, G. S.; Pesticidas: Rev. Tecn. Cient. 1996, 6, 13.

7. Grue, C. E.; Hart, A. D. M.; Mineau, P. In CholinesteraseInhibiting Insecticides. Chemical in Agriculture Series; Mineau, P., ed.; Elsevier Scientific Publishers B.V.: Amsterdam, 1991, vol. 2 , ch. 5 .
8. Edwards, C. A.; Fisher, S. W. In Cholinesterase-Inhibiting Insecticides. Chemical in Agriculture Series, Mineau, P., ed.; Elsevier Scientific Publishers B.V.: Amsterdam, 1991, vol. 2, ch. 3 .

9. Barceló, D.; Hennion, M.-C. In Techniques and Instrumentation in Analytical Chemistry, Barceló, D.; Hennion, M.-C., eds.; Elsevier Science Publishers B.V.: Amsterdam, vol. 19, 1997.

10. Andreescu, S.; Barthelmebs, L.; Marty, J.-L.; Anal. Chim. Acta 2002, 464,171

11. Bonnet, C.; Andreescu, S.; Marty, J.-L.; Anal. Chim. Acta 2003, $481,209$.

12. Nunes, G. S.; Jeanty, G.; Marty, J.-L.; Anal. Chim. Acta 2004, 523, 107.

13. Marques, P. B. O.; Nunes, G. S.; Santos, T. C. R.; Andreescu, S.; Marty, J.-L.; Biosens. Bioelectron. 2004, $20,825$.

14. Fest, C.; Schmidt, K. J.; The Chemistry of Organophosphorus Pesticides: Reactivity Synthesis, Mode of Action and Toxicity, Springer-Verlag Heidelberg: New York, 1973.

15. Noblet, J. A.; Smith, L. A.; Suffet, I. H.; J. Agric. Food Chem. 1996, 44, 3685.

16. Bucur, B.; Andreescu, S; Marty, J.-L.; Anal. Lett. 2004, 37, 1571.

17. Evtugyn, G. A.; Budnikov, H. C.; Nikolskaya, E. B.; Talanta 1998, 46, 465.

18. Nunes, G. S.; Montesinos, T.; Marques, P. B. O.; Fournier, D.; Marty, J.-L.; Anal. Chim. Acta 2001, 434, 1.

Received: August 9, 2005 Published on the web: April 28, 2006 